УДК 502.14

DOI: https://doi.org/10.26642/jen-2020-1(91)-112-115

В.А. Швець, аспірант

Міжрегіональна академія управління персоналом

\title{
Основні положення реалізації державної екологічної політики в умовах глобалізації
}

\author{
(Представлено: д.держ.упр., проф. Драган І.О.)
}

\begin{abstract}
Зазначено, щзо екологічний правовий порядок є системою закріплених законодавством юридичних способів реалізації державної екологічної політики у сфері регулювання екологічних відносин, де предметом регулювання є відносини власності на природні ресурси, використання природних ресурсів, відносини з охорони навколишнього середовища від забруднення, виснаження і руйнування, а також відносини з охорони екологічних прав $і$ законних інтересів фізичних та юридччих осіб. Державна екологічна правова політика спрямована на створення нормативноправової основи, яка дозволяє регулювати екологічні прочеси, щуо відбуваються у суспільстві в інтересах особистості, громади і держави, забезпечуючи сталий розвиток.

Обтрунтовано, щ⿻о основою реалізації державної екологічної політики є сукупність конституційних прав і свобод, щу визначають: використання й охорону природних ресурсів як основи життя і діяльності населення; володіння природними ресурсами, щчо не завдає шкоди навколишньому середовищу; заохочення діяльності, щзо сприяє екологічному $i$ санітарноепідеміологічному захисту населення; забезпечення права кожного на сприятливе навколишнє середовище $i$ достовірну інформачію про його стан, на відшкодування збитків, завданих здоров'ю або майну екологічним правопорушенням; обов'язок кожного зберігати природу $i$ навколишнє середовище, дбайливо ставитися до природних багатств.

Визначено, щзо засади державної екологічної політики в умовах глобалізачії потрібно удосконалити за допомогою реалізації таких заходів: впровадження ресурсо-, енергозберігаючих та екологічно безпечних технологій у всіх сферах господарювання, враховуючи промисловість, сільське господарство, енергетику, транспорт $i$ комунальне господарство; формування потужних господарських структур для створення необхідних умов реалізації програм з переходу регіонів до сталого розвитку; застосування регіонального принципу охорони природного середовища та управління використанням природних ресурсів.
\end{abstract}

Ключові слова: державне регулювання; державна екологічна політика; екологічний порядок; глобалізація; охорона природного середовища; екологічні відносини.

Постановка проблеми. Екологічна ситуація, що складається в світі й у нашій країні, вимагає формування нових підходів до вирішення екологічних проблем. У межах таких підходів сучасна державна екологічна політика має бути спрямована не стільки на охорону природного середовища, скільки на його оздоровлення.

Сучасні екологічні процеси, пріоритетні напрями гарантування національної безпеки і потреби в оптимізації відносин у сфері використання і охорони природи вказують на необхідність вдосконалення напрямів реалізації державної екологічної політики з метою реалізації екологічних інтересів країни, що $€$ частиною системи життєво важливих інтересів особистості, суспільства і держави в умовах глобалізації. Суттєвою перешкодою в реалізації екологічних інтересів $\epsilon$ слабка концептуальна розробленість державної екологічної політики, що негативно впливає на сферу правового забезпечення регулювання екологічних процесів.

Аналіз останніх досліджень і публікацій. Найбільший розвиток дослідження проблем реалізації державної екологічної політики отримало в роботах таких авторів, як: Г.В. Анісімова, І.Н. Личенко, К.А. Машненков та інших. Питання соціальної екології та екологічних відносин, екологізації економіки в сучасних умовах екологічної кризи розглядаються в роботах I.В. Шевченко, Д.І. Якушева. Проте недостатньо розкритими залишаються питання визначення шляхів удосконалення реалізації державної екологічної політики в умовах глобалізації.

Метою статті $є$ подальший розвиток основних положень реалізації державної екологічної політики в умовах глобалізації.

Викладення основного матеріалу дослідження. Сфера екології є значущим фактором суспільного життя, а екологічні проблеми, що виникають у різних регіонах світу, сьогодні мають глобальне значення. У більшості регіонів світу порогові значення екологічної рівноваги близькі до критичних у контексті розвиненого антропогенного тиску на природу. Тому екології часто віддається пріоритет у державній

(C) В.А. Швець, 2020 
політиці сучасних держав, консолідованих міжнародними інституціями, договірними відносинами i нормами міжнародного законодавства у вирішенні екологічних проблем.

Механізми правового регулювання екологічних відносин мають містити такі правові норми, що реалізують сукупність екологічних прав і свобод:

- норми, що регулюють господарську діяльність, трудові та службові відносини, які виникають у процесі господарської діяльності та забезпечують реалізацію екологізованих господарсько-правових приписів;

- норми, що регулюють охорону навколишнього середовища та використання природних ресурсів;

- норми, необхідні в тих випадках, коли суб'єкти не хочуть вступати у правовідносини або не виконують покладені на них обов'язки.

Екологічний правовий порядок $є$ системою закріплених законодавством юридичних способів реалізації державної екологічної політики в сфері регулювання екологічних відносин, де предметом регулювання $\epsilon$ відносини власності на природні ресурси, використання природних ресурсів, відносини 3 охорони навколишнього середовища від забруднення, виснаження і руйнування, а також відносини 3 охорони екологічних прав і законних інтересів фізичних та юридичних осіб.

Державна екологічна правова політика спрямована на створення нормативно-правової основи, яка дозволяє регулювати екологічні процеси, що відбуваються у суспільстві в інтересах особистості, громади і держави, забезпечуючи сталий розвиток [3, с. 400].

Екологічні відносини - це сукупність зв'язків між людьми, які формуються у процесі взаємодії людини 3 природою, що є необхідною умовою їі життєдіяльності. Такі відносини є частиною системи суспільних відносин, обумовлені змістом економічних, політичних, правових та культурних зв'язків, які характеризують суспільну і державну системи. До їх основних груп належать природокористування, охорона навколишнього середовища, збереження екологічного балансу. Учасниками екологічних відносин є: людина, органи державної влади та громадського самоврядування, громадські, міжнародні та міжурядові організації.

Суб'єктом екологічних відносин є особистість, суспільство і держава, об'єктом - природні ресурси, сприятливе навколишнє середовище, здоров'я населення країни. Екологічні відносини, які виникають в суспільстві, є основою екологічного процесу, який являє собою діяльність суб'єктів екологічних відносин, засновану на пріоритетах економічного розвитку, що концептуалізується державною соціальною політикою, яка здійснюється на основі законності, що спрямована на реалізацію екологічного інтересу.

Змістом екологічних правовідносин є екологічні права людини і громадянина, які являють собою визнані міжнародним співтовариством і закріплені в національному законодавстві невід'ємні можливості індивіда, що дозволяють забезпечити його потреби в захисті навколишнього середовища як елементу сталого розвитку в інтересах нинішнього і майбутнього поколінь людей $[1$, с. 33].

Екологічний правовий порядок грунтується на регульованих правом екологічних відносинах і являє собою систему закріплених законодавством юридичних способів реалізації державної екологічної політики у сфері регулювання екологічних відносин, де предметом регулювання є відносини власності на природні ресурси, використання природних ресурсів, відносини 3 охорони навколишнього середовища від забруднення, виснаження і руйнування, а також відносини з охорони екологічних прав i законних інтересів фізичних та юридичних осіб [5, с. 80].

Основою реалізації державної екологічної політики є сукупність конституційних прав і свобод, що визначають: використання і охорону природних ресурсів як основи життя і діяльності населення; володіння природними ресурсами, що не завдає шкоди навколишньому середовищу; заохочення діяльності, що сприяє екологічному і санітарно-епідеміологічному захисту населення; забезпечення права кожного на сприятливе навколишнє середовище і достовірну інформацію про його стан, на відшкодування збитків, завданих здоров'ю або майну екологічним правопорушенням; обов'язок кожного зберігати природу і навколишнє середовище, дбайливо ставитися до природних багатств.

Процеси глобалізації та суспільних трансформацій підвищили пріоритетність збереження довкілля, а отже, потребують від держави вжиття термінових заходів. Протягом тривалого часу економічний розвиток України супроводжувався незбалансованою експлуатацією природних ресурсів, низькою пріоритетністю питань захисту довкілля, що унеможливлювало досягнення збалансованого (сталого) розвитку.

Запровадження екологічно безпечних, ресурсо- та енергозберігаючих технологій, розвиток відновлюваних джерел енергії, нематеріального природокористування відбуваються безсистемно і надто повільно. В умовах підвищення ціни на газ необхідно вжити значних системних заходів, спрямованих на підвищення енергоефективності, декарбонізацію енергетичного сектору та розвиток джерел відновлюваної енергетики [6, с. 93].

У сфері безпеки і оборони має бути вирішене питання доступу до об'єктів військово-оборонного промислового комплексу для здійснення відповідного нагляду та контролю за дотриманням на цих 
об’єктах природоохоронного законодавства, запобігання забрудненню поверхневих та грунтових вод нафтопродуктами, знищенню природних ландшафтів тощо з метою мінімізації наслідків діяльності на цих об'єктах, що сприятиме реформам у сфері безпеки і оборони та впровадженню стандартів НАТО. Запровадження міжнародних стандартів систем екологічного управління на підприємствах і в компаніях сприятиме розвитку системи управління навколишнім природним середовищем та реалізації в Україні міжнародних природоохоронних ініціатив [2].

Тому в майбутньому потрібно удосконалити засади державної екологічної політики в умовах глобалізації за допомогою реалізації таких заходів:

- впровадження ресурсо-, енергозберігаючих та екологічно безпечних технологій у всіх сферах господарювання, враховуючи промисловість, сільське господарство, енергетику, транспорт і комунальне господарство;

- формування потужних господарських структур для створення необхідних умов реалізації програм 3 переходу регіонів до сталого розвитку;

- застосування регіонального принципу охорони природного середовища та управління використанням природних ресурсів.

Для підвищення ефективності реалізації державної екологічної політики недостатньо визначити напрям діяльності державних органів, слід також забезпечити їх правову регламентацію і фінансування. Потрібно, щоб зазначеними функціями наділялися відповідні органи, причому система цих органів має відповідати умовам необхідності і достатності, маючи на увазі не тільки визначення кола суб'єктів діяльності, а й наділення їх відповідною компетенцією, встановленням ієрархічної співпідпорядкованості органів і заходів відповідальності як самих органів, так і їх посадових осіб.

Висновки. Отже, на сучасному етапі реалізації державної екологічної політики в умовах глобалізації необхідно сформулювати такі його завдання: модернізація економічного механізму природокористування та охорони навколишнього середовища 3 внесенням відповідних змін до податкового і бюджетного законодавств; конкретизація природоохоронних норм і вимог, спрямована на стимулювання соціально-економічного розвитку та поліпшення екологічних умов проживання людини; спрощення оформлення дозвільної документації для природокористувачів; підвищення дієвості та ефективності контролю і нагляду в сфері природокористування й охорони навколишнього середовища; вдосконалення екологічного правового порядку в частині забезпечення реалізації природоохоронних повноважень громадян і громадських організацій.

Перспективи вдосконалення напрямів реалізації державної екологічної політики України пов'язані 3 посиленням ролі їі регіонального компонента і передбачають розширення прав органів місцевої влади у сфері регулювання екологічних відносин. У чинному екологічному законодавстві регіональний компонент екологічної політики надзвичайно низький через несуттєву роль, яку відіграють територіальні суб'єкти, відповідальні за цей напрям діяльності. Розвиток екологічного законодавства має бути спрямований на правову інституціоналізацію діяльності місцевих органів влади в сфері охорони навколишнього середовища, контроль за природокористуванням, враховуючи законодавчу діяльність у цій сфері.

\section{Список використаної літератури:}

1. Анісімова Г.В. Актуальні проблеми законодавчого забезпечення екологічних інтересів у державній політиці України / Г.В. Анісімова // Теорія і практика правознавства. - 2018. - Вип. 2. - С. 32-43.

2. Закон України «Про Основні засади (стратегію) державної екологічної політики України на період до 2030 року» : документ 2697-VIII, чинний, редакція від 01.01.2020 [Електронний ресурс]. - Режим доступу : https://zakon.rada.gov.ua/laws/show/2697-19.

3. Личенко I. Екологічна безпека як об'єкт адміністративно-правового забезпечення у нових соціальнополітичних умовах / І.Личенко // Вісник Національного університету «Львівська політехніка». Серія : Юридичні науки. - 2017. - № 865. - С. 398-404.

4. Машненков K.A. Формування та реалізація державної екологічної політики в умовах війн інформаційної доби / К.А. Машненков // Державне управління та місцеве самоврядування. - 2018. - Вип. 2. - С. 95-101.

5. Шевченко I.B. Стратегічна екологічна оцінка як інструмент екологічної політики України / I.B. Шевченко // Економіка України. - 2016. - № 10. - С. 79-86.

6. Якушев Д. Сучасні тенденції державної екологічної політики в Україні в контексті концепції сталого розвитку / Д.Якушев // Державне управління та місцеве самоврядування. - 2016. - Вип. 4. - С. 92-97.

\section{References:}

1. Anisimova, G.V. (2018), «Problems of legislative support of environmental interests in the state policy of Ukraine», Teoriya i praktika pravovedeniya, Issue 2, pp. 32-43.

2. Verkhovna Rada of Ukraine (2020), About the basic principles (strategies) of the state environmental policy of Ukraine for the period until 2030, the law of Ukraine, [Online], available at: https://zakon.rada.gov.ua/laws/show/2697-19 
3. Lysenko, I. (2017), «Ecological safety as an object of administrative and legal support in the new socio-political conditions», Visnik Natsionalnogo universitetu «Lvivska politehnika», seriia Yuridichni nauki, No. 865, pp. 398-404.

4. Mashnenkov, K.A. (2018), «Formation and implementation of state environmental policy in the wars of the information era», Derzhavne upravlinnya ta mistseve samovryaduvannya, Issue 2, pp. 95-101.

5. Shevchenko, I.V. (2016) «Strategic environmental assessment as an instrument of environmental policy of Ukraine», Ekonomika Ukrayini, No. 10, pp. 79-86.

6. Yakushev, D. (2016) «Modern trends in state environmental policy in Ukraine in the context of the concept of sustainable development», Derzhavne upravlinnya ta mistseve samovryaduvannya, Issue. 4, pp. 92-97.

Швець Валерій Андрійович - аспірант Міжрегіональної академії управління персоналом.

Наукові інтереси автора:

- теоретичні підходи до сучасного державного управління;

- сфера екології;

- реалізації державної екологічної політики.

https://orcid.org/0000-0003-0895-0310 